\title{
TRANSFORMASI TEKNOLOGI PRESENTASI
}

\author{
Dody Doerjanto \\ Jurusan Desain, Universitas Negeri Surabaya \\ Email: dodydoerjanto@unesa.ac.id
}

\begin{abstract}
ABSTRAK
Sinkronisasi antara pengetahuan dan perkembangan teknologi sejajar sepanjang zaman. Meskipun Dosen selalu disibukkan dengan penelitian, pengabdian, dan pembelajaran, tetapi kurang waktu mengembangkan pengetahuan untuk mempercantik teknologi presentasi yang digunakan setiap hari. Mereka hanya mengetahui perkembangan teknologi secara teoritik dan terpisah-pisah. Padahal perkembangan teknologi komputasi telah diatur sebegitu mudahnya, agar dapat digunakan dalam satu paket perangkat pembelajaran yang sangat menarik. Makalah ini bertujuan untuk menambah pengetahuan dan pengalaman dalam bidang pembelajaran, diilhami secara filosofis untuk penerapan metode berbasis teknologi, agar presentasi tidak stagnan seperti yang digunakan selama ini di perguruan tinggi. Perkembangan teknologi komputasi dengan strategi pembelajaran selayaknya dieksplor untuk menghadapi revolusi industry 4.0. Strategi yang perlu ditempuh adalah melakukan transformasi teknologi komputasi, agar presentasi yang digunakan dapat berkembang sesuai dengan kebutuhan pembelajaran. Proses pembelajaran membutuhkan perangkat teknologi yang lugas dan mudah digunakan, agar materi mudah diserap dan tidak mudah dilupakan. Wujud yang diharapkan dalam kajian ini, menghasilkan presentasi yang lebih menarik dan mudah dilakukan untuk menyajikan presentasi yang lebih professional.

Kata kunci: Transformasi, sinkronisasi, eksplorasi, teknologi presentasi
\end{abstract}

\section{PENDAHULUAN}

Masih banyak yang membantah bahwa dosen selama ini memang kekurangan waktu untuk memelajari presentasi pembelajaran mulai tahun 1999 sampai 2018. Tidak peduli bagi yang sudah menyandang gelar profesor sampai baru memeroleh gelar doktor. Sedikit sekali yang punya waktu untuk membedah teknologi komputasi, barang kali mungkin juga tidak ada yang berkemauan, karena mereka hanya perlu meneliti dan mengembangkan bidang mereka sendiri. Kelihatannya hal seperti ini mungkin juga sangat merepotkan. Karena bidang komputasi tidak linier dengan kebutuhan pengakuan keahlian mereka. Hal ini sangat tidak dibutuhkan bagi para profesor dan calon-calon profesor.

Mengamati proses pembelajaran, selama saya belajar pada strata tiga pada tahun 2010, semua profesor memresentasikan materi kuliah menggunakan teknologi komputasi 2004. Mereka masih menganggap bahwa itu adalah satu-satunya teknologi yang paling menarik untuk memresentasikan tulisan dan gambar, meskipun yang mereka kuasai hanya sebatas menganimasi, memunculkan kata, menyembunyikan huruf, menerbangkan gambar dan membumbui sedikit audio berisik yang hanya tersedia dalam program. Memang lebih mudah menggunakan template yang tersedia dari pada merancang dan menciptakannya. Ahhh... lagi-lagi tidak ada waktu, tenaga, kemampuan, ketrampilan dan pengalaman untuk mengembangkannya. Sungguh pekerjaan sejenis ini hanya kebutuhan para tukang teknologi untuk mengerjakannya. Mereka rupanya sudah melupakan akar kelahiran teknologi pembelajaran yang mengangkat diri mereka sendiri mendapatkan gelar sebagai seorang doktor dan profesor teknologi pembelajaaran. Berikut ini adalah sisa-sisa presentasi yang saya peroleh dari akhir perkuliahan di perguruan tinggi program studi teknologi pembelajaran tahun 2015 yang saya cintai. 

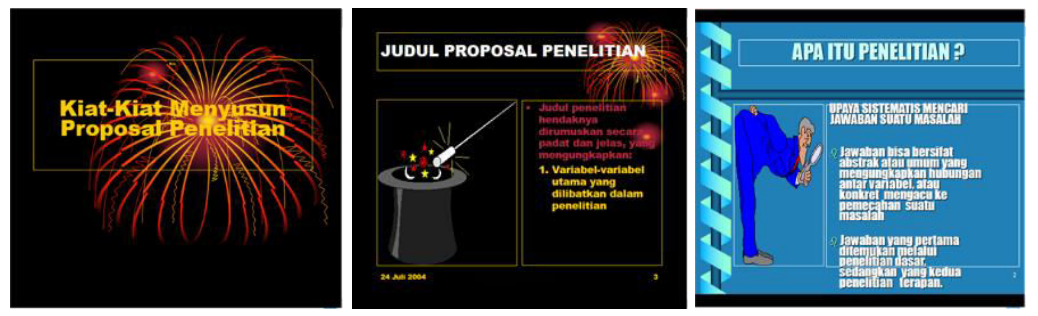

Gambar 1. Layar presentasi powerpoint 2004-2007.

Ini bukan sebuah ironi. Tetapi kita kehabisan tenaga untuk menguasai teknologi. Rupanya gelar yang membebani pundak ini, hanya sekedar mengejar linieritas ilmu yang kita miliki dan dihargai. Rupanya kita dibelenggu misi yang selama ini mengikat antara ilmuwan, pemikir, perancang, dan tukang. Padahal mereka tidak mengetahui bahwa teknologi sejenis ini pada zamannya, sudah bisa digunakan sebagai teknologi untuk memresentasikan materi multi media full audio visual. Seperti bagiannya dihubungkan antar layar, antar presentasi, atau antar materi yang tersedia di internet. Apalagi teknologi komputasi masa kini, dua tahun sekali mereka dikembangkan tanpa henti. Kalau dahulu mereka mengatur sendiri untuk memenuhi kebutuhan sendiri. Tetapi sekarang mereka berkolaborasi antar program. Sehingga teknologi komputasi saat ini, direkayasa agar mereka dapat digunakan untuk melakukan transformasi, sinkronisasi dan eksplorasi presentasi.

\section{TEORI PENGEMBANGAN DALAM PEMBELAJARAN}

Barangkali terlalu banyak teori pengembangan selama ini yang kita pelajari. Kita pernah mengenal System Approach Model for Designing Instruction Dick \& Carey, Komponen Model Jerold Kemp, AT \& T Instructional Development Model, 4D Model (Define, Desain, Develop, Diseminate), Bloomes Taxonomy, Gagné's 9 Events of Instruction, ASSURE: Instructional Design Model, dan Instructional Systemic Design Smith, P.L., \& Ragan, T.J. Dalam Instructional Systemic Design (ISD) baca Darryl L. Sink dalam Chapter 11 Design Models and Learning Theories for Adults (2014: 181). (Smith, P., \& Ragan, 1993) menyatakan diantaranya bahwa Instructional technology is the theory and practice of design, development, utilization, management and evaluation of processes and resources for learning. Instructional Systemic Design (ISD) is a system procedures for developing education and training in a consistent and reliable fashion.

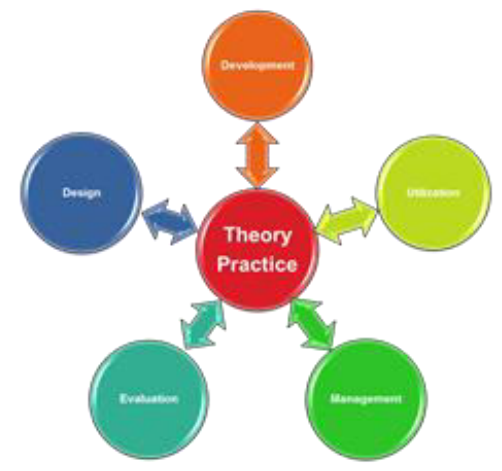

Gambar 2. Diagram ISD.

Kita juga pernah mengenal Instructional Design (ID) menunjukkan adanya proses yang sistematik untuk menerjemahkan prinsip-prinsip belajar dan pembelajaran ke dalam rencana untuk menciptakan materi dan aktivitas pembelajaran. Sedangkan ISD merupakan proses yang terdiri dari tahap-tahap yang sistematik dan sistemik untuk merencanakan aktivitas pembelajaran. Yang cukup menarik adalah implementasi ISD selama ini digunakan Bisnis dan Industri, Desain pelatihan dan penggunaan teknologi militer, Medis dan kesehatan, Sekolah, Perguruan tinggi, Sistem pendidikan terbuka dan jarak jauh, dll. 
Memang untuk menyelesaikan permasalahan instruksional diperlukan seorang desainer. Menurut (Sink., 2014) pekerjaan dari seorang instructional designer adalah menjawab beberapa pertanyaan tentang objective, metode, strategi, dan evaluasi berikut:

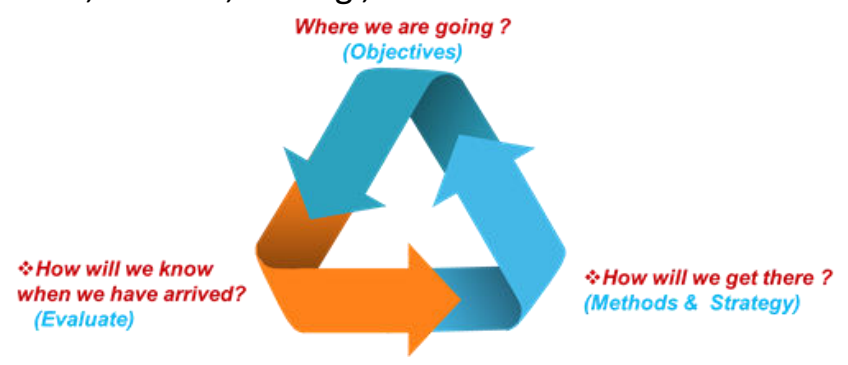

Gambar 3. Diagram ID.

Secara rasional pemikiran sejenis ini menciptakan pembelajaran yang efektif, efisien, menarik (appealing), membantu koordinasi, menjamin kesesuaian antara tujuan, aktivitas, dan penilaian hasil belajar. Sebagaimana kita ketahui keterbatasan ISD itu memerlukan identifikasi hasil belajar yang ingin dicapai, memerlukan waktu, dan tidak dapat diaplikasikan untuk mengatasi masalah non-instruksional. Namun demikian, sebenarnya cukup menarik karena ISD itu memiliki empat pilar karakteristik sistem sebagai berikut:

Interdependent bahwa setiap elemen tidak dapat dipisahkan dari sistem karena saling bergantung satu sama lain untuk mencapai tujuan.

Synergistic berarti secara bersama-sama sebuah sistem dapat mencapai output yang lebih besar daripada yang bisa dicapai oleh setiap komponennya secara individual.

Dynamic bahwa sistem dapat melakukan adaptasi dengan lingkungan dan secara konstan selalu memonitor lingkungannya.

Cybernetic bahwa semua elemen dalam sistem saling berkomunikasi satu sama lain.

Analisis terhadap model-model ISD menunjukkan bahwa pada umumnya model-model ISD memiliki beberapa kesamaan komponen yaitu: Analysis, Design, Develop, Implement dan Evaluate yang biasa kita kenal sebagai ADDIE.

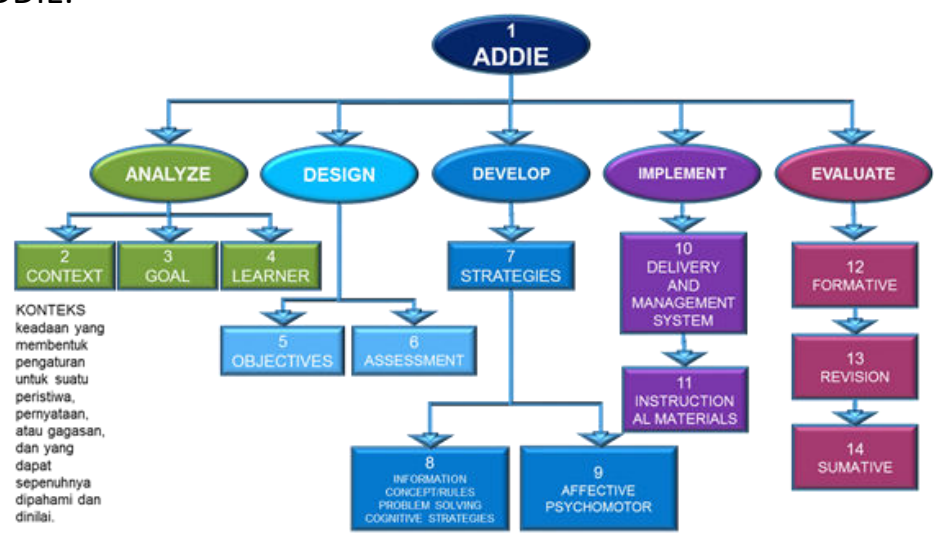

Gambar 4. Diagram ADDIE.

Analysis dalam proses ISD sering dikaitkan dengan langkah analisis kebutuhan (need assessment) yaitu menentukan masalah pembelajaran yang valid yang terjadi dalam suatu unit analisis.

Design mempunyai makna adanya beberapa langkah yang spesifik yaitu: menentukkan tujuan pembelajaran yang akan dicapai, menglasifikasikan jenis dan aktivitas pembelajaran yang akan diimplementasikan, serta menentukan media pembelajaran yang akan digunakan.

Develop adalah proses mewujudkan blue-print alias desain tadi menjadi kenyataan. Jika dalam desain diperlukan suatu software berupa multimedia pembelajaran atau modul cetak, maka harus dikembangkan. Begitu pula halnya dengan lingkungan belajar lain yang akan mendukung proses pembelajaran semuanya harus disiapkan dalam tahap ini. Satu langkah penting dalam tahap pengembangan adalah uji coba sebelum diimplementasikan. 
Implementation meliputi pelaksanaan proses dan aktivitas pembelajaran dalam setting atau situasi yang telah ditentukan. Implementasi mempunyai makna menerapkan rancangan yang telah dibuat dalam setting yang telah ditetapkan.

Evaluation meliputi proses evaluasi formatif dan evaluasi sumatif. Evaluasi formatif adalah yang berupaya menemukan kelemahan program untuk direvisi. Evaluasi formatif adalah evaluasi yang bertujuan untuk mengetahui efektivitas program.

Bagian ini sungguh membangkitkan minat untuk mengembangkan eksplorasi teknologi komputasi sebagai sarana pembelajaran aktif, inovatif, kreatif, efektif, menarik, menantang, dan barangkali belum tentu menyenangkan bagi semua pihak dalam menyongsong revolusi industri 4.0. Sebab kita bukan hanya menyiapkan sarana dan prasarana yang memadai tetapi perlu didukung suasana ruang yang nyaman ditempati untuk menunjang proses pembelajaran.

Artikel ini bukan sekedar teori untuk mentransformasi presentasi biasa, tetapi diusahakan menjadi sebuah penyajian presentasi sebagaimana menyaksikan siaran di televisi. Rancangan ini adalah pengalaman yang selama ini dibangun untuk menyajikan presentasi lebih baik, menarik dan berusaha membangkitkan kreativitas, semangat belajar, emosi dan inovasi.

\section{METODE PERANCANGAN}

Rancangan pembelajaran diatur sebagaimana telah disepakati, baik secara tertulis maupun secara verbal. Proses pembelajaran adalah proses yang di dalamnya terdapat kegiatan interaksi antara guru-siswa dan komunikasi timbal balik yang berlangsung dalam situasi edukatif untuk mencapai tujuan belajar (Rustaman, N.Y., 2003). Dalam proses pembelajaran, dosen (pembelajar) dan mahasiswa (pebelajar) merupakan dua komponen yang tidak bisa dipisahkan. Namun demikian, tugas dosen perlu merancang pembelajaran mulai dari kemampuan awal (input) pebelajar, proses pembelajaran melalui pertemuan tatapmuka (face to face, on-line dan off-line), masih dikontrol kualitasnya oleh badan penjaminan mutu agar hasilnya memuaskan sesuai dengan tujuan yang direncanakan.

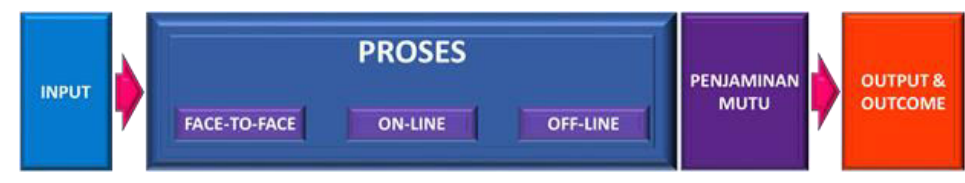

Gambar 5. Landasan proses pembelajaran.

Teknologi komputasi yang selama ini disajikan dalam kelas, melalui perancangan secara filosofis berbasis teknologi pembelajaran. Secara visual kajian ini dapat direkayasa sebagai interdependent, synergistic, dynamic dan cybernetic diantara mereka. Langkah ini digunakan sebagai perwujudan ISD secara konstruktif, untuk membangun pengembangan dan sinkronisasi teknologi pembelajaran. Berikut adalah diagram rancangan pengembangan pembelajaran menggunakan teknologi komputasi dalam matakuliah fotografi yang digunakan di jurusan desain, FBS, Unesa: 


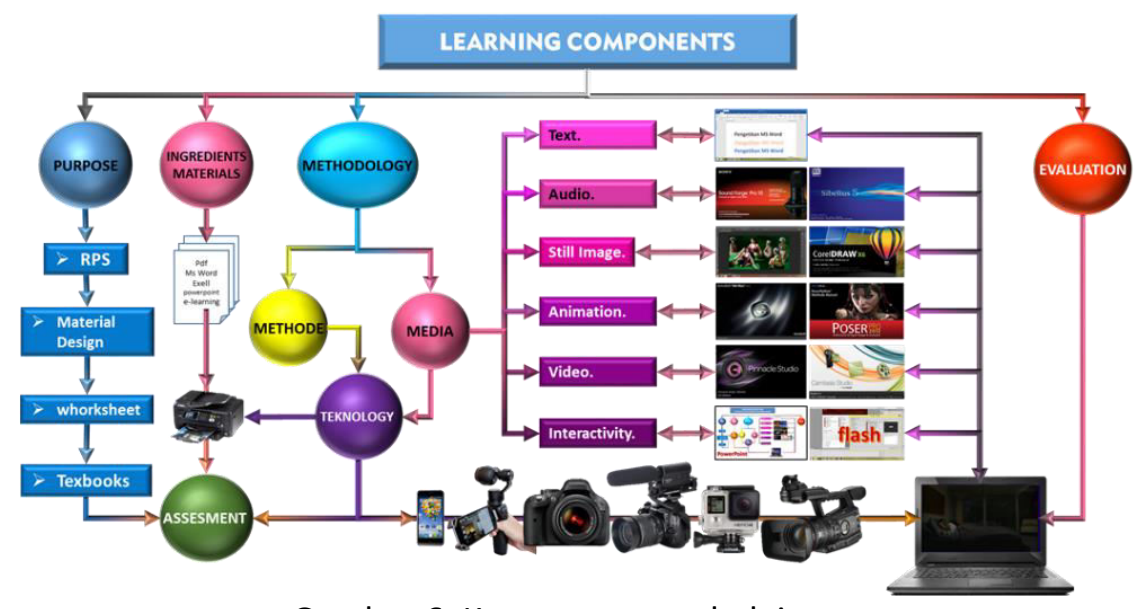

Gambar 6. Komponen pembelajaran.

Komponen pembelajaran pada umumnya terdiri dari tujuan (purpose), materi (material), metodologi (methodology), dan evaluasi (evaluation). Rancangan tujuan pembelajaran adalah kewajiban dosen untuk menyusun tujuan pembelajaran. Penyusunan materi pembelajaran menjadi mutlak ditempuh agar tujuan pembelajaran menjadi jelas, runut, rinci dan terstruktur sehingga dimensi hirarkhinya sudah terlihat pada saat melakukan perencanaan. Hal ini memudahkan menyusun rencana perkuliahan semester (RPS) dan materi yang akan disampaikan dalam pembelajaran. Setelah itu dilanjutkan memilih metode, media dan teknologi komputasi yang digunakan, dan diakhiri dengan evaluasi.

Dalam perancangan metodologi pembelajaran, sudah biasa dosen melakukan penyajian secara verbal, melalui ceramah, diskusi, tanya jawab dan berusaha sekuatnya menyajikan media yang menarik dan menyenangkan. Pada bagian ini yang paling perlu dikembangkan untuk menyongsong revolusi industri 4.0 adalah pemilihan dan penggunaan media pembelajaran. Sebab media pembelajaran pada masa mendatang mungkin sudah tidak lagi menggunakan layar lebar, tetapi sudah menggunakan televisi yang besar. Hal ini sudah dikembangkan di amerika dengan menggunakan layar sentuh pada televisi yang berukuran besar. Tentu saja pembelajaran menjadi sangat menarik, karena pebelajar bisa terlibat secara aktif dan langsung menggunakan media yang tersedia. Pada saat menulis dipapan sudah tidak perlu lagi menggunakan kapur, spidol papan, dan sejenisnya. Pembelajar tinggal memilih jenis huruf, warna, dan bisa juga menulis di layar lebar dengan tangannya sendiri dihadapan para pebelajaran secara langsung.

Daftar teknologi komputasi yang digunakan untuk menunjang komponen pembelajaran

Tabel 1. Teknologi komputasi pilihan

\begin{tabular}{|c|c|c|c|}
\hline No & Kebutuhan & Program Aplikasi & Fungsi \\
\hline 1 & Teks & Microsoft-Office Word & Pengetikan naskah, \\
\hline \multirow{2}{*}{2} & \multirow{2}{*}{ Audio } & Sound Forge pro 10 & Mengolah data sound \& musik \\
\hline & & Sibelius & Mengolah nada-nada musik \\
\hline \multirow[b]{2}{*}{3} & \multirow[b]{2}{*}{$\begin{array}{l}\text { Gambar } \\
\text { diam }\end{array}$} & Adobe Photoshop CS6 & Untuk mengolah gambar, foto, 2D, 3D dsb. \\
\hline & & $\begin{array}{l}\text { Corel Draw graphic } \\
\text { shuite } \mathrm{X} 6\end{array}$ & Mengolah gambar, cover, gambar 2D, 3D, dsb. \\
\hline \multirow[b]{2}{*}{4} & \multirow[b]{2}{*}{ Animasi } & Adobe Premier 6.5 & Untuk mengolah film, cd, dvd \\
\hline & & $\begin{array}{l}\text { Meta Creation Poser } 5 \\
\text { Poser Pro } 2012\end{array}$ & $\begin{array}{l}\text { Menganimasi gerakan hewan dan manusia, hanya } \\
\text { berlaku pada layar computer yang lebar untuk } \\
\text { menunjukkan pilihan gambar dan pengaturan yang } \\
\text { besar. }\end{array}$ \\
\hline 5 & Video & Pinacle Studio 15 & Mengolah data film, cd, dvd \\
\hline
\end{tabular}




\begin{tabular}{|c|l|l|l|}
\hline & & Camptasia Studio 7 & $\begin{array}{l}\text { Merekam semua kegiatan dalam bentuk film pada } \\
\text { layar computer. }\end{array}$ \\
\hline \multirow{2}{*}{$\mathbf{6}$} & \multirow{2}{*}{ Interaktivitas } & $\begin{array}{l}\text { Microsoft-Office } \\
\text { PowerPoint }\end{array}$ & presentasi, animasi, audiovisual, interaktif \\
\cline { 3 - 4 } & & Flash & presentasi, animasi, audiovisual, interaktif \\
\hline
\end{tabular}

Tentu saja teknologi komputasi ini bisa dipelajari secara bertahap, bila masih tersedia waktu untuk menyinkronkan teknologi yang tersedia. Tetapi kita yakin para profesor sudah terlalu sibuk, tidak mungkin punya waktu untuk memelajarinya dari awal. Namun secara pasti, kita juga hanya menggunakan teknologi komputasi powerpoint yang dianggap familier selama ini, dan memang dianggap sangat mudah untuk memresentasikan materi pembelajaran, tetapi tidak dioptimasi secara tuntas. Akibatnya penampilan presentasi menjadi biasa saja. Padahal masih dapat dikembangkan interaktifitasnya, sehingga penyajian materi pembelajaran menjadi lebih ringan, lebih mudah, lebih menarik, dan menyenangkan. Tentu saja daftar komputasi yang tertulis diatas itu, perlu dibuktikan apakah memang benar dapat mengubah transformasi, sinkronisasi, eksplorasi, dan teknologi presentasi.

\section{PENERAPAN}

Selama ini pengguna presentasi hanya menggunakan format secara langsung yang tersedia dalam program. Padahal telah disediakan ukuran format pilihan untuk menyesuaikan kebutuhan sejak program ini diciptakan. Oleh karena pengguna belum tahu caranya, atau enggan menentukan format ukur, maka yang kita lihat selalu terlalu sederhana, menggunakan ukuran yang sama pada setiap presentasi bagi semua pengguna.

\subsection{Standar Pemilihan Format}

Penyajian format presentasi selama ini menggunakan ukuran 4:3. Hal ini menyesuaikan ukuran format layar bentang, dengan perbandingan yang sama dengan format layar komputer. Pada pilihan yang lain disediakan format yang bervariasi. Hanya saja kita sering kali tidak meneliti ukuran yang disediakan untuk memenuhi kebutuhan presentasi layar yang dibutuhkan.

Yang tersedia pada template powerpoint 2016 terdapat 25 (duapuluh lima) pilihan. Kita tinggal menggunakan secara bergantian agar tidak membosankan. Dan yang paling penting kalau bisa merancang format sendiri, tentu saja akan lebih menyenangkan. Gambar berikut adalah format template yang tersedia pada teknologi komputasi powerpoint 2016 dan pengembangan desain.
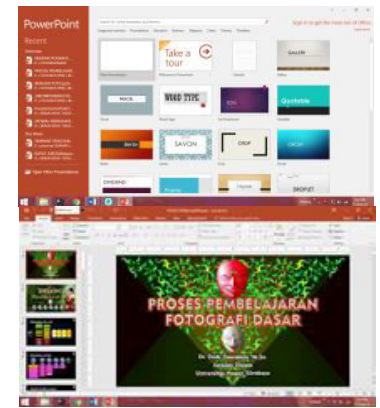

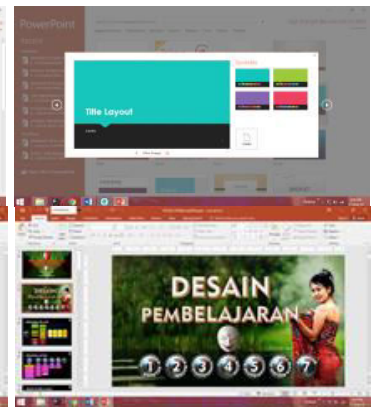

Gambar 7. Format yang tersedia dan pengembangan.

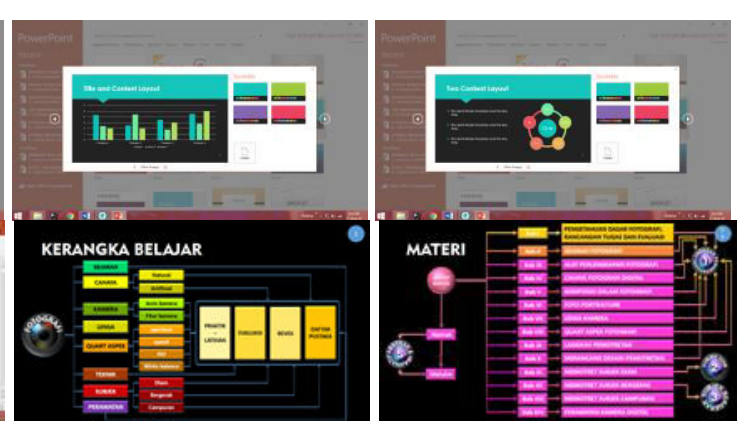

(3)

Dengan cara mengatur desain presentasi, dapat dipilih ukuran yang hampir sama penampakannya dengan layar bentangan yang tersedia, yaitu 4:3, letter paper 8,5:11 inc, ledger paper 11:17 inc, A3 paper 297:420 mm, A4 paper 210X297 mm, B4 (ISO) paper 176X250 mm, 35 mm slides, overhead, dan custom. Yang paling sesuai dengan layar komputer dan sinkron dengan layar televisi adalah on-screen show 16:9 dan widescreen. 

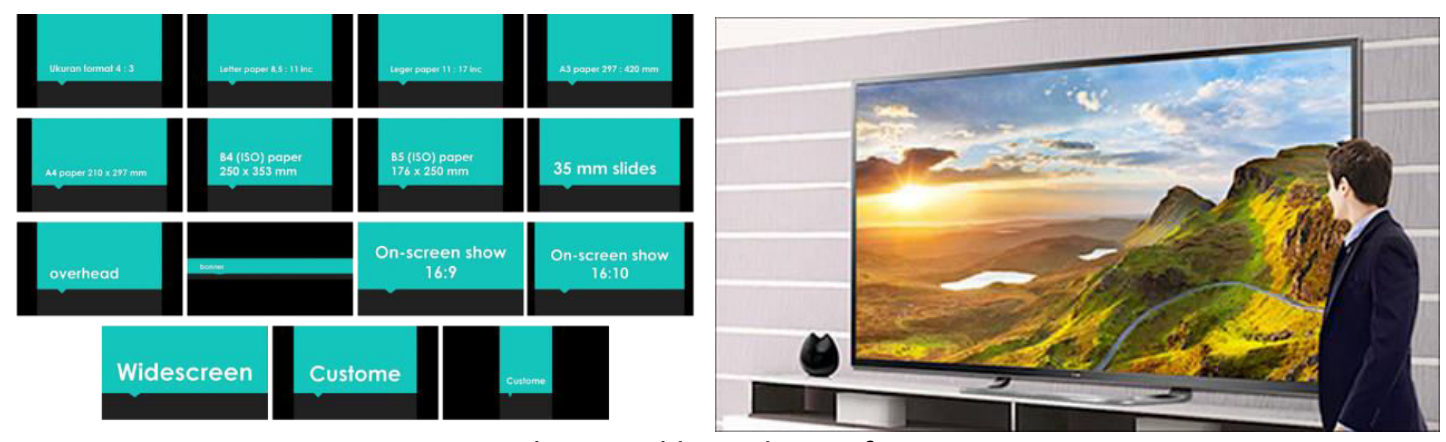

Gambar 8. Pilihan ukuran format.

Keuntungan memilih standar ukur pemilihan format adalah dapat digunakan secara optimal sinkronisasi antara perancangan komputer, video dengan televisi jaman now. Sebab bila pada saat penyajian tidak disediakan layar bentangan dapat menggunakan televisi monitor LCD ukuran 80 inc untuk 30 peserta. Akan menjadi lebih menarik bila setting penyajian touch screen, sehingga merangsang minat semua peserta untuk terlibat menyentuhnya.

Disamping itu juga diperlukan standar pengukuran isi presentasi pembelajaran. Yang selama ini digunakan meliputi pembuka presentasi, mengendalikan, menentukan indikator, isi materi pembelajaran, pengukuran dan penutupan acara presentasi. Agar tidak membosankan, maka isi materi diatur agar dapat melibatkan animasi tulisan, gambar, audio, dan video tanpa menghentikan layar presentasi. Berikut adalah rancangan presentasi pembelajaran yang dapat dikembangkan sesuai kebutuhan pembelajaran.

\section{STANDARD LEARNING THOROUGHT}

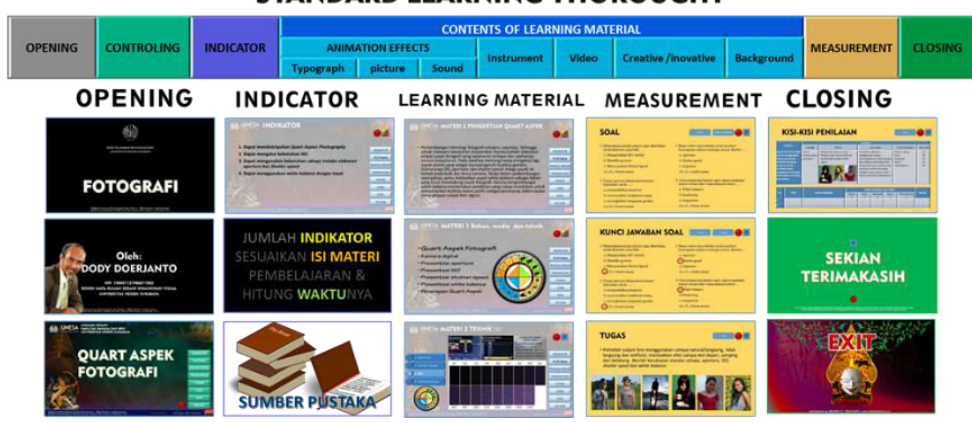

Gambar 9. Standar pengembangan presentasi pembelajaran.

\subsection{Pembuka Presentasi}

Membuka presentasi diupayakan memacu pikiran peserta belajar (pebelajar) agar terfokus pada materi yang akan disampaikan oleh pemberi pelajaran (pembelajar). Agar lebih menarik pada layar pertama, sisipkan unsur musik terkini (up to date) atau video pendek, agar pelajaran dibuka dengan lantunan yang terisi suara (instrumen musik) atau video yang menyenangkan sebagaimana pembuka acara pada televisi. Atur pergantian slide secara otomatis melalui transisi, sehingga tidak merepotkan untuk mengklik mouse komputer.
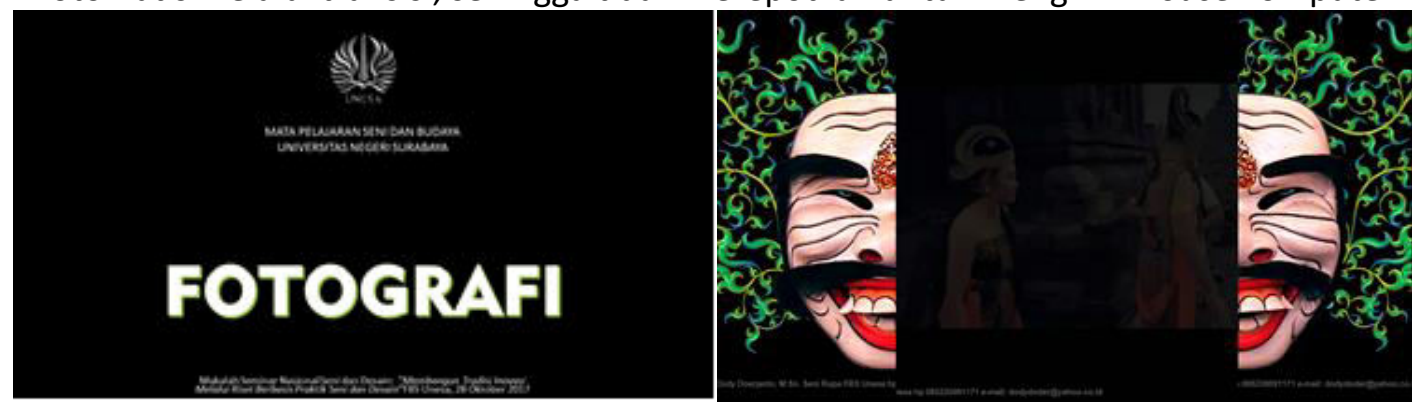
Gambar 10. Pengembangan pembuka presentasi.

Agar presentasi pembelajaran mudah diingat oleh pebelajar, pada layar ke dua, sisipkan foto presenter dan identitas pembelajar agar tidak mudah diganti, diakui, dan digunakan pembelajar lain. Pada awalnya saya ditertawakan mahasiswa pada tahun 1999, mereka menyebutnya "narsis" ketika foto saya cantumkan di awal dan diakhir pertemuan. Tetapi sekarang malah banyak yang menggunakan dimana saja.

Bila berkeinginan untuk dibagikan tanpa bayar kepada pebelajar, sebaiknya disimpan dalam format pdf. Meskipun banyak cara mengubah isi presentasi tetapi cukup menyulitkan bagi orang yang belum mengenal program. Bila tanda-tanda pada presentasi ini disisipkan tanda penghubung (link), masih berlaku untuk menunjukkan bagian yang dibutuhkan dalam format pdf.

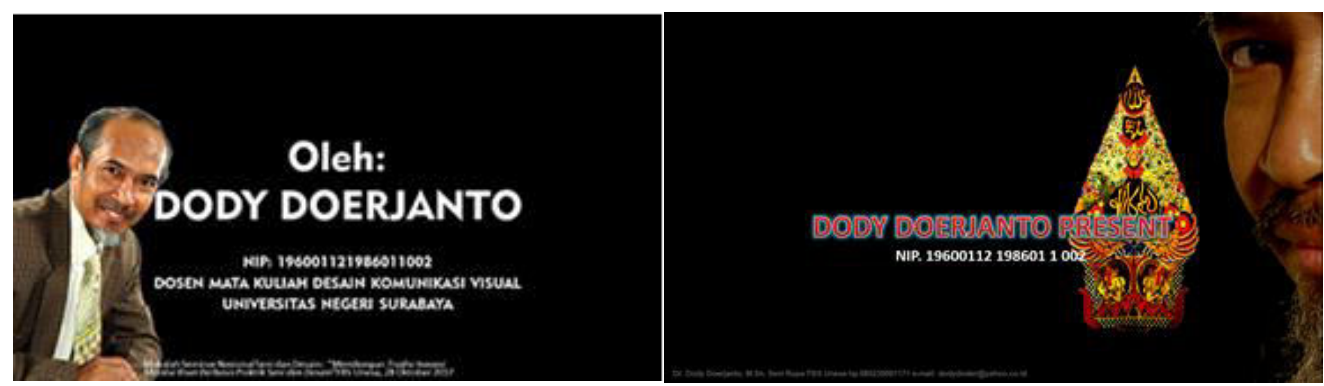

Gambar 11. Identitas pembelajar.

\subsection{Merancang Background presentasi.}

Rancangan background pesentasi sangat memengaruhi perhatian visual. Meskipun tersedia banyak pilihan, lebih menarik bila dapat mendesain sesuai dengan kebutuhan. Kita bisa menentukan warna dalam format background, tekan gradient fill, kita akan tersaji background lereng (gradient) berwarna. Dapat juga dilakukan dengan cara mengatur sendiri gambar-gambar di layar monitor. Setting ukuran bisa dilakukan dengan menekan print on screen (PrtSc). Dilanjutkan membuka adobe photoshop, menekan File New, tekan Ok, kemudian tekan kontrol V, setelah itu kita bisa mengedit bagian-bagian yang diperlukan.
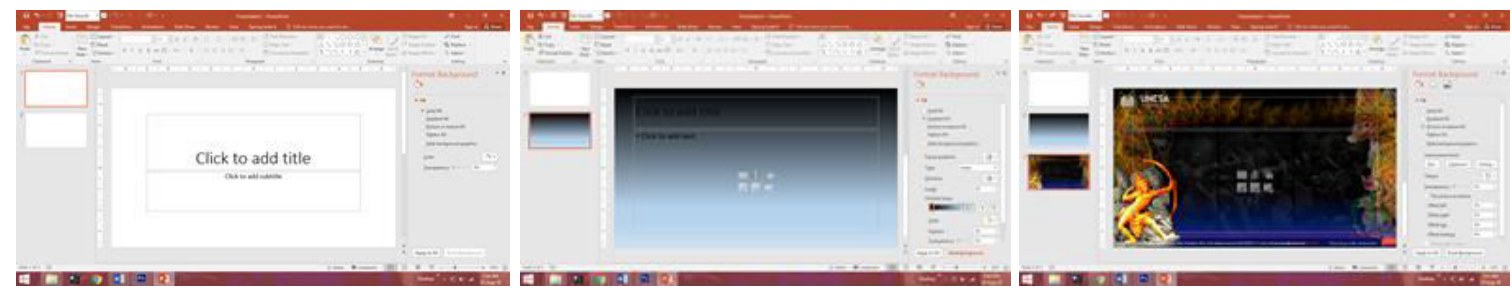

Gambar 12. Desain background.

\subsection{Home Base Presentasi}

Setelah itu ditampilkan layar ketiga, berisi judul materi dan ikon pengendali untuk dihubungkan (link) dengan isi materi pembelajaran secara lengkap, yaitu

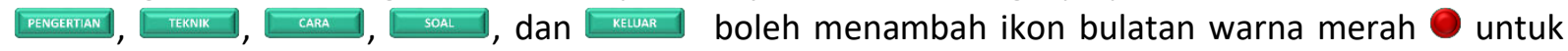
keluar tanpa meninggalkan pesan. 


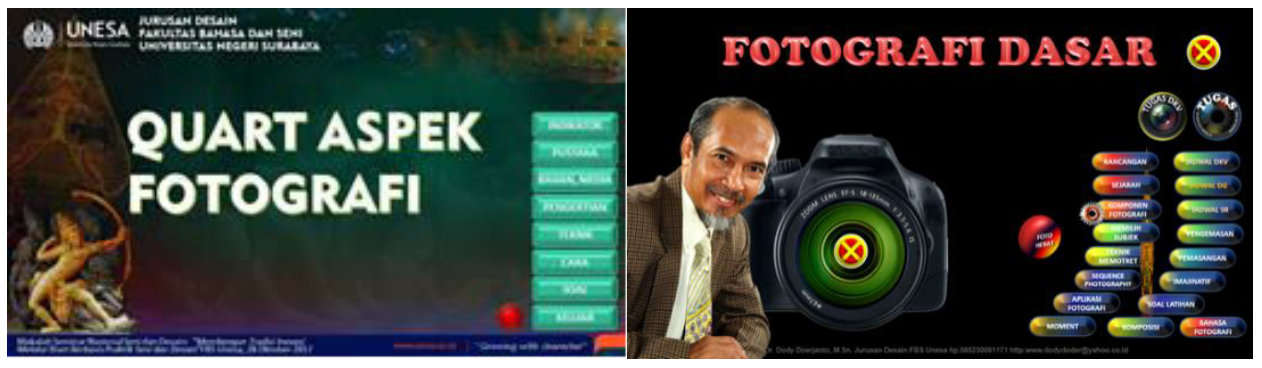

Gambar 13. Pengembangan Home base.

Kosongkan transisi pada layer ini, agar ikon link berfungsi secara optimal dan layar tidak berpindah tempat sembarangan ketika melakukan klik melalui mouse.

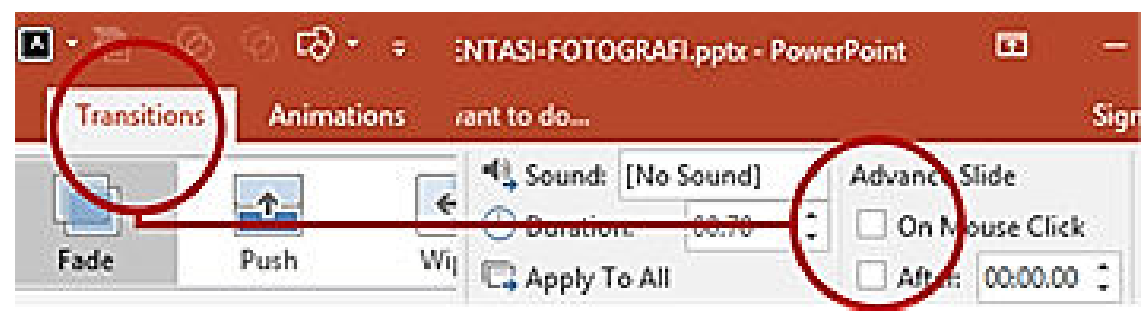

Gambar 14. Mengatur transisi.

\subsection{Sasaran Pembelajaran}

Layar ke empat berisi indikator pencapaian hasil pembelajaran. Karakter pada indikator perlu disusun berdasarkan pentahapan hirarkhi sasaran hasil capaian pembelajaran dengan jelas dan terukur kualitasnya.

Jumlah indikator disesuaikan dengan isi materi pembelajaran dan dihitung waktunya sesuai dengan batas waktu yang telah dirancang dan ditentukan dalam RPS sebelumnya. Pada layar ini perlu mulai menambah ikon keluar tanpa pesan dan kembali ke menu utama (home base) 술으.
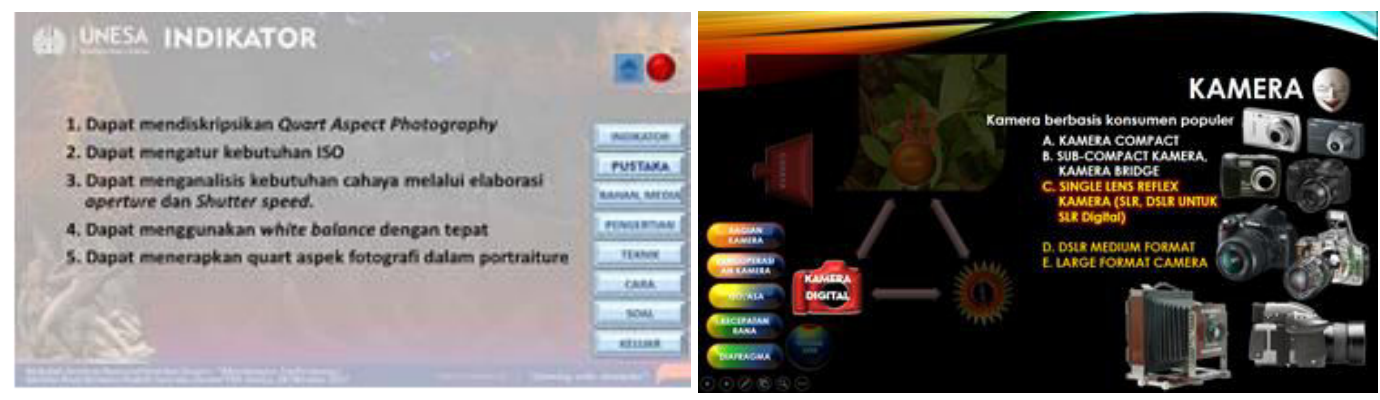

Gambar 15. Sasaran pembelajaran.

\subsection{Sumber Pustaka}

Layar kelima, berisi sumber pustaka yang digunakan dalam pembelajaran, sesuai dengan RPS yang direncanakan. Perlunya menyantumkan daftar pustaka yang digunakan, agar pebelajar dapat melanjutkan secara mandiri untuk menambah pengetahuan lebih mendalam. 


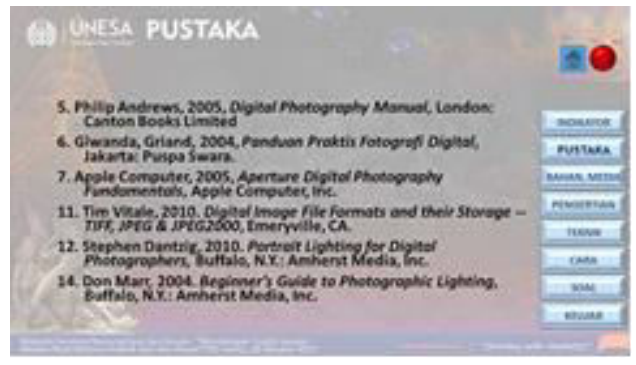

Gambar 16. Daftar pustaka.

\subsection{Isi Presentasi}

Layar keenam, berisi materi pembelajaran tentang quart aspek fotografi. Terdiri dari materi kamera digital lengkap dengan semua fitur kamera. Ringkasan penggunaan aperture, atau penjelasan lengkap melalui presentasi aperture dapat dilengkapi dengan animasi huruf, gambar, musik intrumen, dan video tentang pengunaan aperture. Ringkasan presentasi ISO, shutter speed, white balance, dan penerapan quart aspek fotografi disajikan secara bertahap dan berurutan.

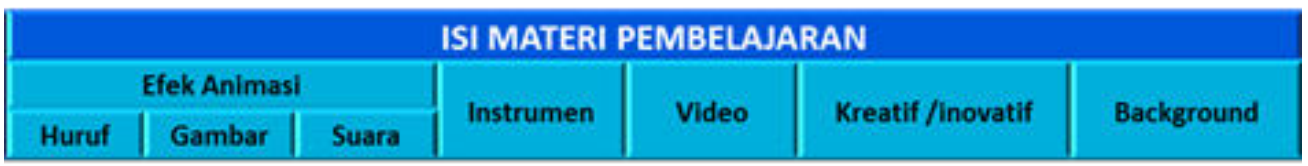

Gambar 17. Penerapan Isi materi pembelajaran.

Pada bagian ini, pembelajar dapat mengembangkan inovasi baru untuk meningkatkan kualitas pembelajaran berbasis PAIKEM (Pembelajaran Aktif, Inovatif, Kreatif, Efektif, dan Menyenangkan) yang terlalu lama digemborkan tanpa batas. Bagian ini dapat diisi suara yang direkam sendiri melalui powerpoint. Dapat mengembangkan semua jenis fasilitas animasi yang telah disediakan, dapat pula memasukkan seluruh isi video atau sebagian isi video dengan cara memotong sesuai dengan kebutuhan waktu yang diperlukan. Karena powerpoint 2010 dan 2016 sudah menyediakan fitur untuk memotong video, maka pembelajar dapat mengatur waktu panjang-pendek video sesuai kebutuhan. Perlu diketahui bahwa vitur ini (insert-video) selalu disembunyikan bila pengguna tidak menyisipkan video dalam layar. Pengaturan ini dapat dilakukan melalui fitur video tool dengan cara menggeser penanda hijau dan merah untuk mengatur waktu sesuai dengan kebutuhan kecepatan pembelajaran. Caranya dapat disimak pada gambar sebagai berikut:

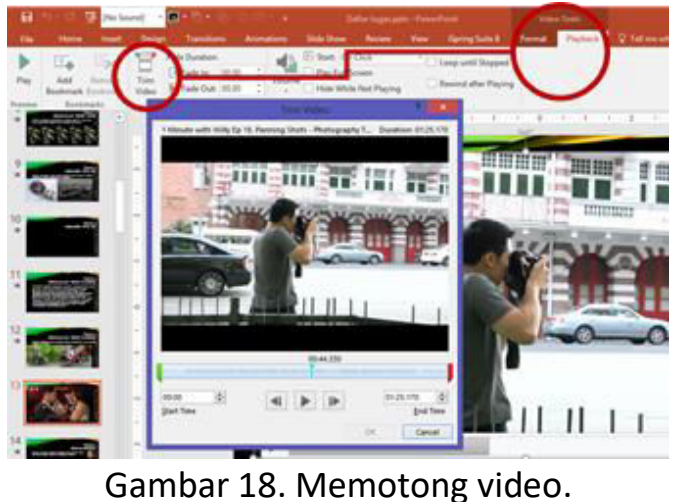

Pada saat inilah perlunya kolaborasi teknologi komputasi. Untuk itu para pembelajar perlu waktu secara mandiri menggunakan teknologi komputasi powerpoint. Oleh karena memang dirancang dengan mudah, maka dapat dikerjakan sendiri dalam upaya meningkatkan ketrampilan menyusun multi media pembelajaran. Kebutuhan teknologi komputasi dapat dilihat pada gambar berikut: 


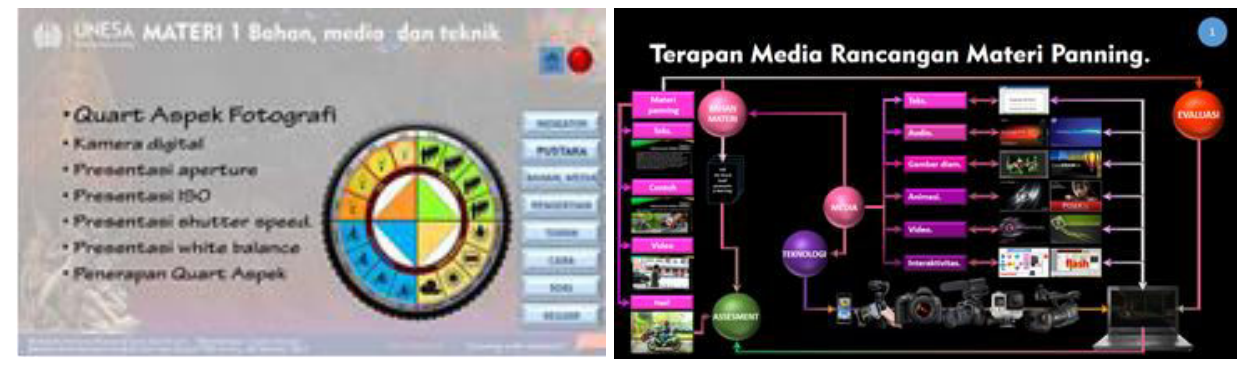

Gambar 19. Materi quart melibatkan variasi teknologi komputasi.

Layar ketujuh, berisi materi tentang quart aspek fotografi secara ringkas. Kelengkapan isinya dapat dilanjutkan melalui penyusunan materi kebutuhan ISO, aperture, shutter speed, dan white balance yang disisipkan pada slide berikutnya atau presentasi yang terpisah.

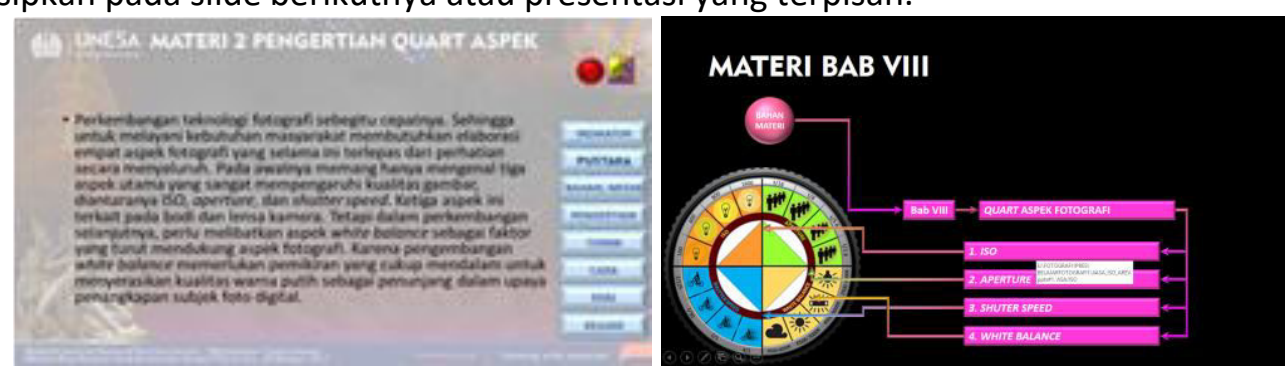

Gambar 20. Materi quart aspek fotografi.

Layar kedelapan, penyajian rincian materi yang berisi penjelasan ringkas atau secara lengkap mengenai ISO, aperture, shutter speed, dan white balance, yang disusun melalui presentasi secara

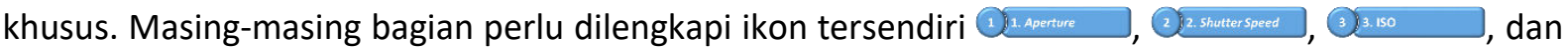
(a) warebaberee, agar dapat dihubungkan secara mudah untuk melengkapi presentasi pembelajaran.

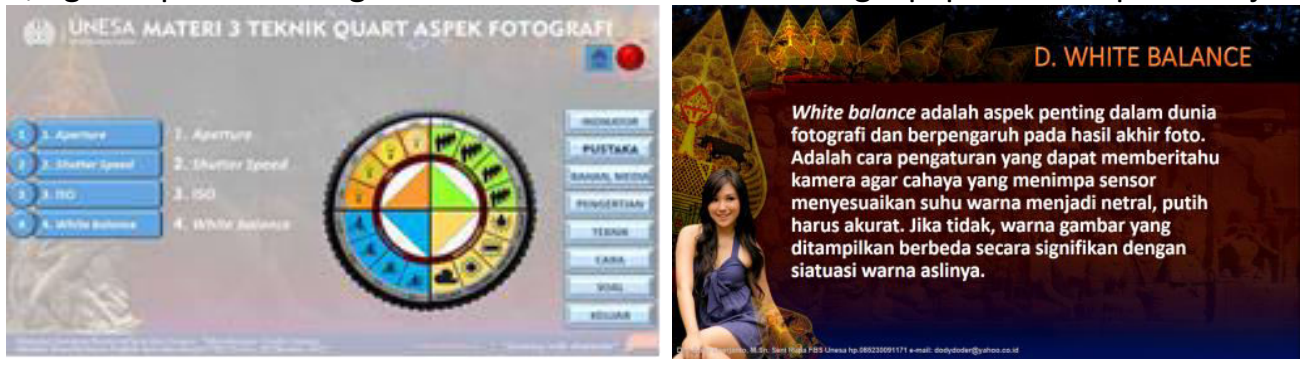

Gambar 21. Materi quart aspek fotografi link dengan white balance.

\subsection{Soal Ujian Materi Presentasi}

Layar selanjutnya, berisi soal untuk mengukur seberapa besar materi quart aspek fotografi dapat diserap dalam pembelajaran. Tidak perlu menggunakan jawaban esay untuk mengukur kemampuan pebelajar, tetapi cukup menggunakan jawaban pilihan ganda agar dapat diukur secara cepat. 

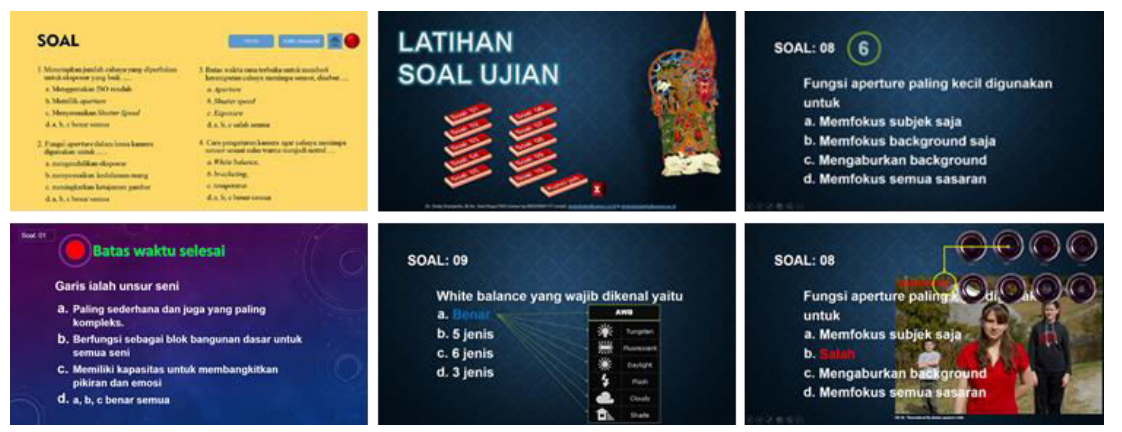

Gambar 22. Pengembangan soal pilihan ganda.

Layar berikut, berisi kunci jawaban, dilengkapi ikon penghubung menuju tugas memotret, agar komunikasi layar dapat dikendalikan dengan mudah.
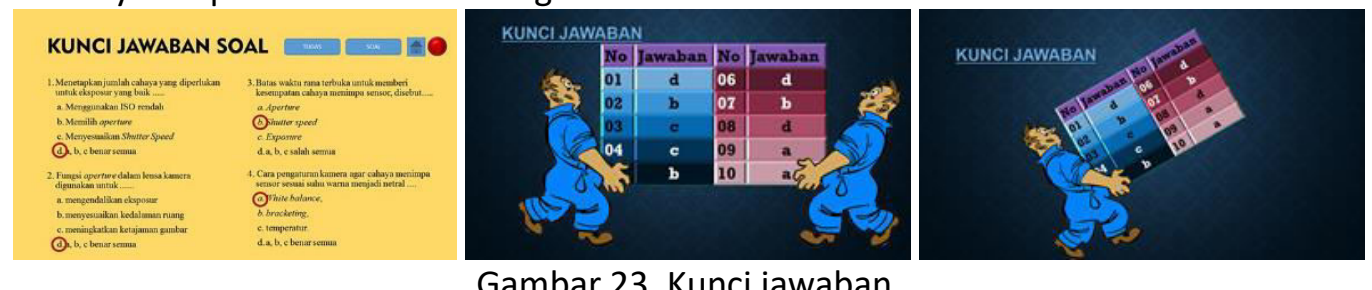

Gambar 23. Kunci jawaban.

\subsection{Tugas}

Layar seterusnya, berisi tugas memotret portraiture, meliputi tugas memotret berdasarkan ketentuan arah cahaya, kedalaman subjek, pemilihan aperture, menerapkan kecepatan rana, pilihan white balance, dan menentukan standar ISO dengan benar. Tugas portraiture cukup signifikan dengan kebutuhan menangkap subjek fotografi secara normal, sebab subjek tidak perlu dirias dan dapat dilakukan pemotretan dengan cepat.

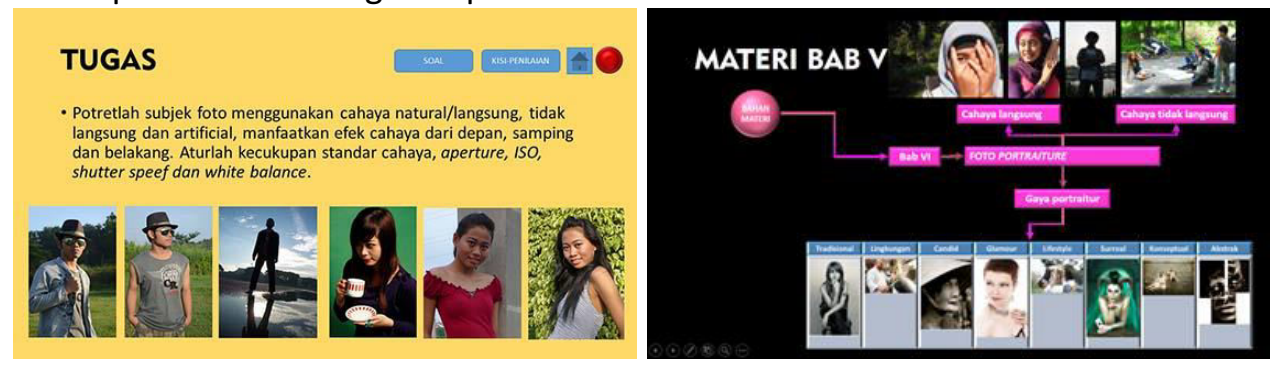

Gambar 24. Tugas foto portraiture.

\subsection{Pedoman Penilaian}

Layar berikut, berisi kisi-kisi penilaian yang digunakan untuk mengukur kualitas hasil pemotretan. Pedoman penilaian ini dibatasi dengan kriteria penilaian dan prosentase bobot penilaian, agar mudah mengukur standar penilaian. Bagian ini bisa digantikan oleh pembelajar lain bila berhalangan melanjutkan proses pembelajaran. 


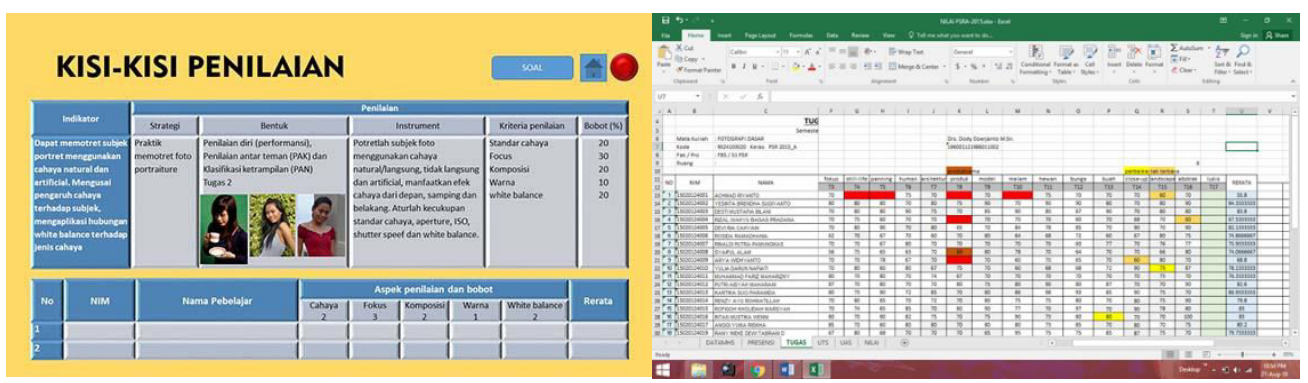

Gambar 25. Pedoman penilaian.

\subsection{Penutup presentasi}

Layar terakhir, berisi penutup presentasi pembelajar untuk menyampaikan ucapan terima kasih bahwa pelajaran fotografi telah dilaksanakan dengan penuh perhatian. Bagian ini dapat disisipi pesan untuk melakukan tindak lanjut.

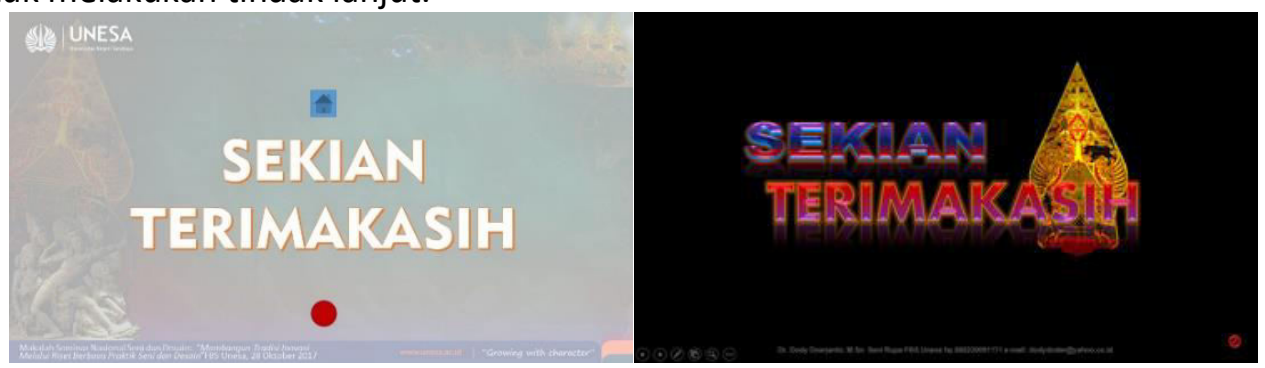

Gambar 26. Pengembangan penutup pembelajaran.

\subsection{Pengembangan lainnya}

Elemen yang dapat dikembangkan dalam teknologi komputasi ini adalah perwujudan visual mulai dari garis, bidang, warna, foto, animasi, dan video. Powerpoint mampu mewujudkan gambar dua dimensi dan tiga dimensi secara mandiri, karena sebagian fitur adobe mulai dari corrections, color, sampai artistics effects sudah tersedia. Selain itu dapat dikolaborasi dengan corelldraw dan adobe photoshop sekaligus lengkap dengan efek gambar yang disediakan. Powerpoint mampu menyajikan gambar sebagai berikut:

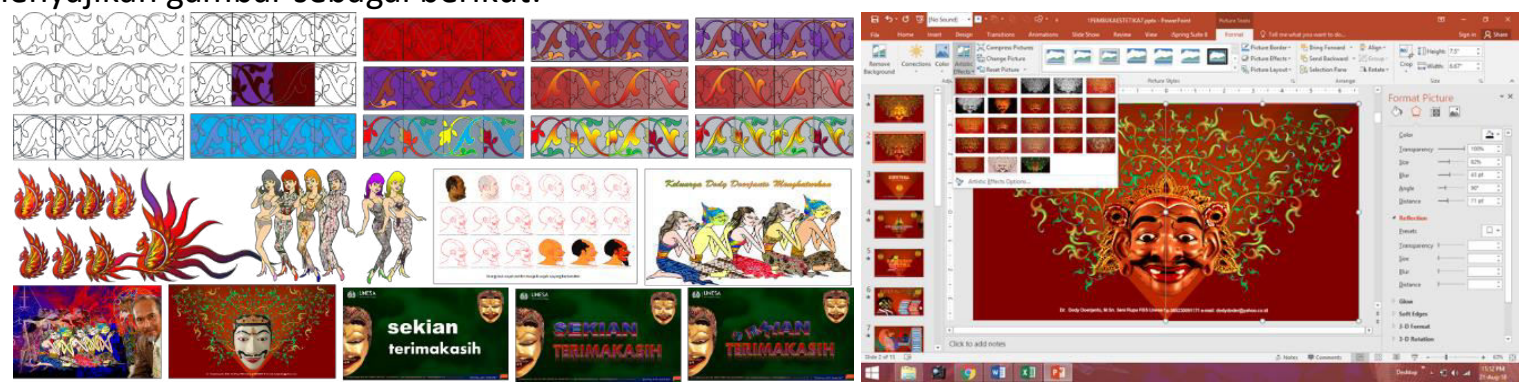

Gambar 27. Kemampuan powerpoint untuk mengembangkan elemen visual.

\section{HASIL PERANCANGAN}

Metode pembelajaran yang dipilih dalam presentasi pembelajaran fotografi, menggunakan kolaborasi antara pembelajaran langsung, pembelajaran tidak langsung, pembelajaran interaktif, belajar melalui pengalaman, dan belajar mandiri. Kelima metode pembelajaran dapat dipadukan secara bergantian untuk memeroleh penyajian presentasi berbasis teknologi komputasi dengan baik. 


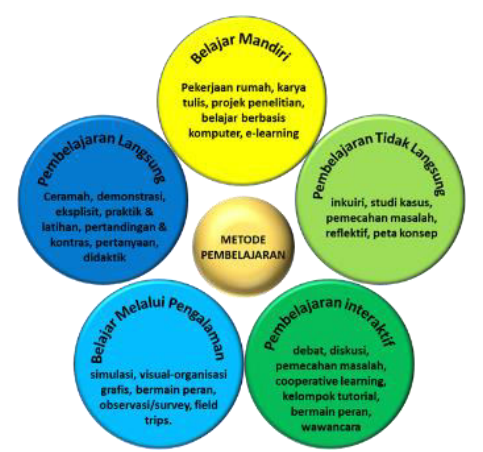

Gambar 28. Metode Pembelajaran.

Kelima metode pembelajaran ini, cukup berhasil untuk mengatasi kesulitan belajar dalam upaya meningkatkan kualitas presentasi pembelajaran. Agar melibatkan semua komponen metode pembelajaran, perlu merancang presentasi pembelajaran hingga melibatkan aktifitas yang saling berkait antara pembelajar dan pebelajar.

Pembuka pelajaran bersuara itu sangat diperlukan untuk menyatukan pemikiran para pebelajar, agar merucut pada sumber pembelajaran yang menarik dan menegangkan. Pengaruh musik dan penataan adegan animasi sangat diperlukan untuk mendukung ekspresi proses pembelajaran, agar pola berfikir pebelajar terseret pada materi yang akan disampaikan.

Seringkali penampilan awal diisi dengan musik dan video pendek, ternyata sangat memengaruhi semangat pebelajar untuk mengikuti proses pembelajaran dengan penampilan yang berbeda. Pembelajar perlu mereduksi teknologi komputasi musik dan video pendek secara bervariasi, karena cukup memicu kesadaran pebelajar untuk mengembangkan inovasi, efektif, kreatif, dan menyenangkan.
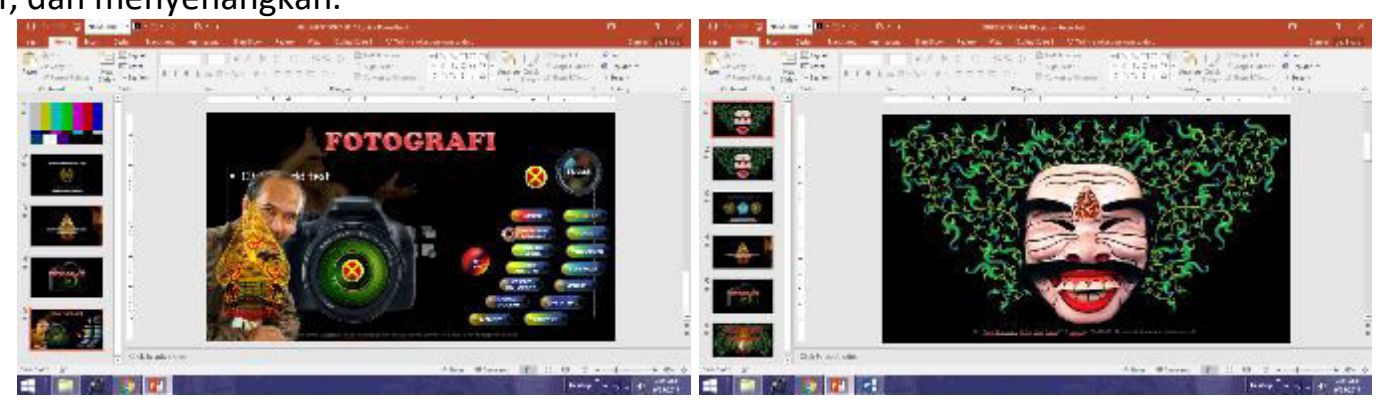

Gambar 29. Dua jenis rancangan pembuka.

Variasi teknologi komputasi dirancang sebegitu mudahnya untuk digunakan dalam pembelajaran. Mengingat waktu yang tersedia sangat terbatas, maka orientasi pemilihan teknologi komputasi perlu dirancang sesuai kebutuhan. Dengan memilih strategi yang baik, presentasi pembelajaran menjadi lebih bervariasi, menarik, menyenangkan dan tidak mudah dilupakan.

Pada akhir materi pembelajaran, selalu diterapkan evalusai secara langsung. Hal ini dilakukan untuk mengukur serapan materi yang telah disampaikan pada waktu yang tidak perlu ditunda. Supaya diperoleh jawaban yang terukur dan meyakinkan keberhasilan proses pembelajaran. Hasilnya dapat digunakan untuk merencanakan tindak lanjut materi berikutnya.

Hasil penyajian presentasi pembelajaran perlu dikembangkan secara bertahap, berjenjang dan berkesinambungan. Kemudian dianalisis, dibandingkan, dievaluasi, dan direvisi dengan harapan untuk mencapai hasil penyajian yang lebih baik.

\section{KESIMPULAN}

Pembelajaran berbasis teknologi komputasi dapat dikembangkan dengan mudah, bila pembelajar menguasai eksplorasi teknologi. Belajar mengembangkan teknologi komputasi 
powerpoint sangat diperlukan untuk meningkatkan kualitas media pembelajaran lebih baik, menarik, menyenangkan membangkitkan minat, dan mengembangkan inovasi baru. Lebih banyak metode yang digunakan, perlu sinkronisasi dalam proses pembelajaran, dengan harapan menghasilkan transformasi presentasi yang menyenangkan. Proses pembelajaran membutuhkan perangkat teknologi yang lugas, dan mudah digunakan. Semua bagian sudah disetting, agar materi mudah diserap dan tidak mudah dilupakan. Wujud transformasi teknologi komputasi, menghasilkan penyajian yang berbeda, mudah dilakukan, dan lebih menarik untuk meningkatkan presentasi lebih professional.

\section{DAFTAR PUSTAKA}

Rustaman, N.Y., D. (2003). Strategi Belajar Mengajar Biologi. Bandung.

Sink., D. L. (2014). Design Models and Learning Theories for Adults.

Smith, P., \& Ragan, T. (1993). Instructional design. Prentice-Hall, Inc. 